\title{
Thailand in 2016
}

Fade to Gray

\begin{abstract}
Events in Thailand during 2016 were overshadowed by the death of long-reigning King Bhumibol Adulyadej on October 13, and the entire nation's mourning. Despite the popular approval of a new constitution in August 2016, Thailand's military regime showed no sign of relinquishing power during this time of considerable national anxiety.
\end{abstract}

KEYWORDS: king, mourning, constitution, elections, human rights

Within minutes of THE Announcement, Facebook pages and news websites across Thailand lost their customary brightness. King Bhumibol Adulyadej, the world's longest-reigning monarch, passed away on October I3, 20I6, and the Thai nation went into mourning monochrome. The death of the ailing 88-year-old King had been widely anticipated: King Bhumibol had spent most of the previous eight years in Siriraj Hospital. Yet after his seven extraordinary decades on the throne, his demise came as an enormous shock to Thais, most of whom had known no other ruler. They had ample reason to be extremely fearful about the future. At the end of 20I6, Thailand lay in metaphorical darkness.

\section{POLITICS}

The National Council for Peace and Order (NCPO), the military junta that seized power in the May 2, 2014 coup, remained firmly in control of the country during 20I6, although the original justifications for the power seizure - the need to prevent violent conflict, heal political divides, and "restore

Duncan McCargo is Professor of Political Science at the University of Leeds, UK, and Visiting Professor of Political Science at Columbia University, New York, USA. Email: <d.j.mccargo@leeds. ac.uk>.

Asian Survey, Vol. 57, Number I, pp. 150-156. ISSN ooo4-4687, electronic ISSN 1533-838X. () 2017 by The Regents of the University of California. All rights reserved. Please direct all requests for permission to photocopy or reproduce article content through the University of California Press's Reprints and Permissions web page, http://www.ucpress.edu/journals.php?p=reprints. DOI: https://doi.org/I0.I525/ AS.2017.57.I.150. 
national happiness" - no longer appeared salient. Political opposition and indeed all forms of dissent had been firmly suppressed through a policy of widespread arrests and intimidation. Critics of the junta had been repeatedly harassed, many of them summoned to military bases to undergo spells of "attitude adjustment." Such measures provoked damning criticism from the UN Human Rights Council and a range of international observers. ${ }^{1}$ Repressing dissenting voices did nothing to bridge Thailand's existing political divides, which persisted just beneath the surface of public life.

The many Thais who supported the regime-including large sections of the Bangkok middle class-continued to tolerate or ignore the military's repression, which did not touch them personally. But for opponents of the regime, including supporters of former Prime Ministers Thaksin Shinawatra, now living in self-imposed exile in Dubai, and his sister Yingluck Shinawatra, who now faces government demands to pay US\$ I billion in compensation for a failed rice program during her tenure in office, happiness remained a distant prospect. For them, the 2014 coup was not a project to create national reconciliation, but a crude attempt to suppress representative democracy. Given the unwelcome prospect of a return to power by proThaksin politicians, the junta seemed in no particular hurry to hold elections, which had initially been promised for 2016 but were later postponed to late 2017 or early 2018.

Military rule in 2016 was clearly both an anachronism and a huge international embarrassment. But as time went on, it became increasingly apparent that the junta had no answers to Thailand's central political problem: how to craft a legitimate polity. Legitimacy was contested, residing alternatively in the electoral system, in the oft-changing constitution, or in the extraconstitutional authority and charisma of the monarch.

Uneasy with a legalist approach, the NCPO seemed initially in no hurry to emulate the 1991 and 2006 coup-makers by drafting a new constitution. After the junta orchestrated the rejection of the 2015 draft constitution prepared under the relatively liberal chairmanship of Bowornsak Uwanno, ${ }^{2}$ the process began again under a new Constitution Drafting Committee chaired by the ever-serviceable veteran conservative jurist Meechai Ruchupan. But even

I. “Thailand: UN Review Highlights Junta's Hypocrisy," Human Rights Watch, May II, 2016, $<$ https://www.hrw.org/news/2016/o5/r/thailand-un-review-highlights-juntas-hypocrisy>.

2. Duncan McCargo, "Peopling Thailand's 20I5 Draft Constitution," Contemporary Southeast Asia 37, no. 3 (2015), pp. 329-354. 
Meechai's draft proved too progressive for the NCPO, whose number two, Prawit Wongsuwan, "suggested" a number of important changes.

Key elements in the 2016 draft constitution were: a wholly appointed senate, effectively hand-picked by the ruling junta; six reserved senate seats for senior security commanders; a lower house comprising 350 constituency MPs and 150 party-list MPs, selected by a multi-member apportionment system; ${ }^{3}$ a continuing role for the NCPO in a 20-year program of reforms; and the option to appoint an unelected prime minister. The provisions for an appointed senate and an unelected prime minister would roll back Thai politics to the early I990s or before. It was an open secret that NCPO leader General Prayut Chan-ocha was eyeing the position of prime minister himself: the new charter could effectively continue the junta's rule long after the proposed election. Following the precedent set by the 2007 constitution, a referendum to approve the draft was set for August 7, providing Thais their first substantive opportunity for political participation in over two years.

\section{CONSTITUTIONAL REFERENDUM}

During the lead-up to the referendum, debate on the constitution was largely suppressed. Politicians and opposition groups were threatened with arrest for raising critical questions about the draft; the vaguely worded and draconian Article 6I of the Referendum Act, which made it illegal to "sow confusion" about the referendum and so promote "disorder," made nonsense of the idea that the public was being seriously consulted. At times, the NCPO's suppression of debate generated into sheer farce. Among those arrested for antireferendum activities were two eight-year-old girls in Khamphaeng Phet, who said they had torn down voter lists to repurpose the pretty pink paper. When scores of monkeys in Pichit vandalized voter lists, prominent law professor Worajet Pakeerat facetiously expressed concern that the macaques might be ill-treated by the authorities.

In June the Election Commission issued a promotional music video entitled " 7 August Referendum, Unite to Secure Democracy," which attracted criticism for portraying northeastern voters as naive and easily manipulated;

3. Multi-member apportionment would adversely affect any large pro-Thaksin party; see Allen Hicken and Bangkok Pundit, "The Effects of Thailand's Proposed Electoral System," Asian Correspondent, February I0, 2016, <https://asiancorrespondent.com/2016/o2/the-effects-of-thailandsproposed-electoral-system/>. 
a week later, the commission was forced to reissue the video with new lyrics. The episode clearly illustrated that the commission was not acting as a neutral election agency but was actively promoting a yes vote by patronizing and misrepresenting those who disagreed with the draft constitution. The same pattern could be seen in a commission leaflet summarizing the draft, which was distributed to every household in Thailand: it glossed over all the controversial features of the charter, explaining neither the proposed electoral system nor the means by which the senate would be selected. Meanwhile, very few Thai voters had even seen a hard copy of the constitution, let alone read its Ios pages and 279 articles from beginning to end. Many people undoubtedly voted for the draft constitution mainly in the hope that this would hasten elections and a return to normalcy. The consequences of voting no remained unclear.

The draft constitution was approved by $6 \mathrm{I} .35 \%$ of those who voted. ${ }^{4}$ An ambiguously-worded second question, asking voters to agree that the next prime minister might be a non-elected figure, was approved by $58.07 \%$. Turnout was $59.40 \%$. The 2007 constitutional referendum had achieved a broadly similar $56.69 \%$ yes vote, and a turnout of $57.61 \%$. But compared with the Prayut government's $80 \%$ turnout target, participation in the 2016 referendum was disappointing. Millions of Thais are "urbanized villagers," registered to vote in rural areas but living and working in and around Bangkok. Very few of these absentees bothered to travel home and cast their ballots.

The 2016 referendum results did not support military narratives about the restoration of national happiness. Despite the NCPO's suppression of dissenting views, around $40 \%$ of the population still voted against the draft charter and an unelected premier. Thailand remained a deeply divided nation: 22 provinces out of 77 rejected the draft, as did the populous northeast region as a whole. The draft was decisively rejected in the Muslimmajority southern border provinces of Pattani, Yala, and Narathiwat-which had comfortably approved the 2007 charter. The "no" vote in the Deep South was a reaction against ill-considered provisions in the draft to grant special protection to Buddhism, and illustrated the sensitivity of religious 
and ethnic issues. ${ }^{5}$ While the polling had been relatively peaceful, a series of bombs went off in southern resort towns in the days following the referendum, killing four people and injuring more than 30 others.

\section{THAI ECONOMY AND FOREIGN RELATIONS}

Thailand's economy remained largely in the doldrums during 20I6. The Asian Development Bank expected GDP growth to reach 3.2\%, a modest improvement on the $2.8 \%$ figure for 20I5, but much lower than both average growth across ASEAN, or the 7.2\% Thailand had achieved under an elected government in 2012. The economy was helped by a fiscal-stimulus program spearheaded by Deputy Prime Minister Somkid Jatusripitak, as well as impressive numbers of tourist arrivals from mainland China. But lengthy royal mourning was expected to dampen domestic economic activity and have adverse impacts on tourism. In the longer term, Thailand faces strong competition for foreign direct investment from both Burma and Vietnam, and continues to be handicapped by infrastructure problems that include a creakingly sclerotic rail system. Thailand's very low birth rate of around I.4 means the working-age population will peak in 2017, deepening reliance on migrant labor in the decades to come.

In June 20I6, Thailand was defeated by Kazakhstan for a rotating seat on the UN Security Council. The scale of the defeat- 138 votes to 55 -illustrated Thailand's relative international isolation since the May 20I4 military coup, despite its serving as 2016 chair of the United Nations' Group of 77, an intergovernmental organization for developing countries. Thailand's brief detention and subsequent deportation of Hong Kong pro-democracy activist Joshua Wong in October was the latest in a series of politicized expulsions apparently designed to curry favor with Beijing, and so to offset American and Western disapproval of the ruling junta. ${ }^{6}$ Yet despite distinctly cool relations with the United States, the annual joint military exercises known as Cobra Gold were staged again in Thailand in February, albeit on a reduced scale.

5. Field notes, Pattani and Narathiwat Provinces, August 5 to 9, 2016.

6. Shawn Crispin, "China-Thailand Relations in the Spotlight with Activist Deportation," The Diplomat, October 7, 2016, <http://thediplomat.com/2016/ro/china-thailand-relations-in-thespotlight-with-activist-deportation/>. 


\section{MOURNING AND SUCCESSION}

For most Thais, the death of King Bhumibol on October 13, 2016, was both highly distressing and somewhat unreal. As Montesano and Chong wrote in a wonderful obituary, "By the middle decades of his reign, the monarchy played a role in Thai life that would have been unimaginable just a few decades earlier. Thais firmly associated it with their self-image as citizens of a successful country."' The King's demise left Thais with much to reflect upon: their memories of a monarch who had personally symbolized the country's remarkable socioeconomic transformation; their hopes and fears about the impending royal succession; and the need to reimagine themselves in a post-Bhumibol Thailand.

Immediately prior to King Bhumibol's death, Crown Prince Vajiralongkorn and other members of the royal family had gathered at Siriraj Hospital. Despite general expectations that the crown prince would quickly be proclaimed king, General Prayut announced that the heir to the throne first wished to mourn his father for an unspecified period. The prime minister declared a one-year mourning period, during which all civil servants would wear only black and white. The next day, as tributes poured in from around the world, the late king's remains were transported to the Grand Palace, watched by huge crowds of mourners gathered around the royal grounds known as the Sanam Luang, where his ceremonial cremation pyre will be constructed.

Shortly afterwards, in a move that surprised many observers, 96-year-old Privy Council President General Prem Tinsulanond was appointed acting regent; former Prime Minister Thanin Kraivichien, age 89, then assumed Prem's Privy Council role. Thailand had embarked upon a highly unusual genuine interregnum. Normally, a regent acts on behalf of a monarch who is not able to perform royal duties, but at this time Thailand had no monarch. ${ }^{8}$ In a further twist, just two weeks after his father's passing Crown Prince Vajiralongkorn quietly left Bangkok for his main home near Munich, without specifying a date for his return. Widespread speculation about the meaning of these developments could not be expressed publicly in Thailand, where a new lèse-majesté crackdown began in the aftermath of King Bhumibol's

7. Michael J. Montesano and Terence Chong, "King Who Won a Place in His Nation's Heart," Straits Times, October I4, 2016.

8. See Article 24 of the 2007 Constitution. 
demise. ${ }^{9}$ These were also uncomfortable times for people who deviated from socially prescribed mourning behavior and sentiments, some of whom faced harassment by zealous royalists. ${ }^{10}$

\section{UPDATE}

On December I, 20I6, Crown Prince Vajiralongkorn-who had flown in from Germany that very morning — was finally proclaimed King Rama X. Rather than reflecting awkward negotiations with the ruling junta, the new King's astrologically propitious 50-day appointment delay illustrated Rama X's determination to rule Thailand entirely according to his own wishes and whims. Although King Vajiralongkorn was quick to reinstall General Prem to the presidency of the Privy Council, new appointments to his advisory body included a number of hardline military officers known for their tough antiThaksin stances. While Thaksin had initially hoped that the new reign might usher in a new political era, even including an amnesty that would allow him to return to Thailand, he was to be bitterly disappointed. Although Thaksin had sometimes previously enjoyed good relations with the Crown Prince, once Vajiralongkorn had attained the throne—and all the attendant resources of the Royal Household and the Crown Property Bureau-the stillambitious former premier had become more old nuisance than future ally.

At the end of 2016, the draft constitution approved by voters in the August referendum had yet to receive royal assent. The schedule for the late King Bhumibol's cremation had not been announced, and the long period of royal mourning meant that mass political demonstrations remained impossible. While in theory a general election could still be held at the very end of 20I7, realistically polls were most unlikely before 20I8. Meanwhile, the passage of a draconian new Computer Crime Act in December 2016 would help the ruling junta suppress online political dissent. But among the first bills to be signed by King Vajiralongkorn was the Haj Activities Support Act, a longstanding aspiration of Thailand's Muslim community; its approval suggested an implicit rebuke to Buddhist chauvinist groups that had opposed the legislation, symbolizing a Kingly sympathy for diversity.

9. "Junta Steps Up Censorship, Surveillance on Lèse Majesté," Prachatai, November II, 20I6, $<$ http://prachatai.org/english/node/669o>.

Io. "Thai Minister Urges 'Social Sanctions' as Mobs Hunt Royal Critics," Daily Mail, October I8, 2016. 